\title{
The Next Generation Internet
}

\section{Government policy and the future of the Internet}

$\mathrm{T}$ he Next Generation Internet (NGI) program was first announced by President Bill Clinton in the fall of 1996 in a speech on research and technology policy. The announcement reflected a renewed federal concern with the development of the Internet and desire to find appropriate ways for the government to help move it forward.

If the administration expected that the bipartisan popularity of the Internet would mean an easy sell in Congress, the first year must have been a disappointment. The FY 98 budget request submitted in March 1997 asked for $\$ 105$ million for the program, but final appropriations fell significantly short of the request. Despite those problems, the program seems to be entering its second year with stronger political legs. Some of the early problems and questions have been dealt with, although there remain some difficult issues.

\section{Evolution of Internet policy}

The science agencies created the Internet principally as an experiment in data communications and as a tool for their researchers. As other public uses such as education, libraries, and health care were folded into the package, the federal government remained the principal sponsor. But over the last several years, as the Internet has grown into a huge global network, federal government policy has come to assume that the net is a viable commercial enterprise whose growth would be mainly driven by private investments in infrastructure and in content. National Science Foundation (NSF) subsidies, which had helped stimulate and guide the early growth of the Internet, were

Rick Weingarten is senior policy analyst at the ALA Washington Office; e-mail: rww@alawash.org eliminated. Only long-term, basic research in networking and support for an experimental networking testbed, the vBNS (very High Speed Network Backbone), remained.

In the last few years, problems and concerns with the growth and viability of the Internet moved some to suggest a renewed effort by the federal government to help move it to the next threshold of capability. Congestion and the rapid growth in use of the Internet have created some disappointment on the part of many users. Response can be slow, particularly when using more complex services that demand higher bandwidth, and many new proposed applications place technological demands on networking technology that it was not designed to provide.

In some sense, the network has been a victim of its own success. Having tasted a limited set of possibilities, many would-be users and service providers are beginning to dream about what could be offered with even more bandwidth and sophisticated transmission services-multicasting of multimedia, interactive educational programming, allocating capacity and capability according to need, and so on. An advanced network could provide full-immersion virtual meeting places for users from remote areas to gather to collaborate on tasks (or just visit). Large, distributed databases could be linked and searched rapidly and efficiently.

Although experts argue about the details, the general characteristics of a future Internet have been set out by the networking community. It has to be scalable in order to support its growth into a truly universal medium. It has to support a wide range of new applications, only a few of which we can imagine today. It must integrate smoothly 
into the existing infrastructure in which so much has already been invested. We can't just simply call the first generation a success, and throw it away, replaced by a newer, better one.

Clearly, the government's role will be much more limited and partial than when DARPA developed the ARPAnet and NSF started NSFnet. The Internet has moved too far, too fast into widespread commercial use for government to replay that scenario. Heavy investments are being made in improved Internet technology by computer and communications firms and users. Service providers are putting in new plants to relieve congestion.

Despite these private efforts, the federal role can be important, particularly in research and development. Private-sector investments are necessarily focused on the short-term technological improvements needed to sustain service to a growing user base. Government can work toward a wider horizon. Furthermore, government agencies such as NASA, the Department of Defense, and NSF have applications that require them to push the leading edge of information technology. They continue to make investments in the development of those applications, and a multiagency program could, in theory, take advantage of these focused agency programs.

\section{New initiatives}

Early in 1996, representatives from research universities began discussing ways to improve the communications infrastructure available on their campuses. Out of those discussions grew a project that came to be known as Internet2. It was essentially intended to be a private initiative, funded by members of an ad-hoc university coalition. As the project gained momentum, so did the number of universities joining it.

In October, when Clinton announced the NGI program, several research universities had already signed on as members of Internet2. Coincidentally, or maybe not, in his description of NGI, Clinton mentioned two specific goals: linking 100 universities and research labs at speeds of ten to a hundred times faster than the current Internet and linking ten or so research labs together at speeds up to 1,000 times the current
Internet speeds. The 100-university proposal sounded to observers a lot like the then ongoing private Internet 2 project. Thus was born one of the standing issues of the NGI program-the relationship among:

1. vBNS: A federally funded very highspeed data communications "backbone" service, supported by NSF as a communications research facility.

2. Internet2: A private university, consortium-led effort to build a new high-speed Internet service for university research, which would use the vBNS as a core backbone for its system, at least in the start-up stages.

3. NGI: A federally funded research and development (R\&D) effort to advance state of the art data communication, which is incorporating connections with Internet 2 as a way to create the experimental network called for by Clinton.

Since the three activities are designed to push Internet technology and its uses forward, it is no surprise and probably desirable that they become intertwined in the NGI program. But this overlap has tended to confuse the message. Is NGI research or is it deployment of advanced systems? If Internet 2 becomes "part" of NGI, is it a private or public facility?

There are arguments for both perspectives, and, realistically, the program will probably always reflect both. But each perspective appeals to a different constituency, both politically and within the research community. Some of the problems NGI had getting accepted by Congress last year were due to that dissonance. Some members of Congress basically said, "Nothing doing unless I see that institutions in my state will benefit directly from deployment." Others in the opposite camp said, "It's the government's job to do R\&D; industry's to deploy. So, why are you building another federally subsidized network?"

\section{Framing the NGI program}

The first step in deciding what work needs to be done and by whom, one needs to answer the more basic question "What is an NGI?" The honest answer is that no one knows exactly. An infrastructure as complex as the current Internet, coupled with the vision that users have for it, suggests that 
Access to government information continues to be a high legislative priority. ALA is committed to working to suppoit government's obligation to create and disseminate easy-to-use government information. To assist the lobbying efforts of the ALA Washington Office, the Government Relations Committee would like to encourage ACRL members to send stories that clearly illustrate the value of government information in education, research, and public affairs. Effective lobbying is often a result of bringing the message home for the legislator. Following is an example of a story taking place in Florida.

\section{Restoration of the Everglades}

The largest environmental restoration project in the history of the world is underway in south Florida. A multi-agency Federal Task Force, a Governor's Commission, the Siminole and Miccosukee Indian tribes, numerous environmental groups, state agencies, and hundreds of researchers are all involved in restoration of the Everglades. A common thread of need throughout the process is access to government information. Thousands of studies, reports, maps, and monographs have been published by federal agencies since the early 1920s detailing treatments and remedies to "problems" in the Florida Everglades.

The Everglades exist in a swath between the rapidly growing Atlantic and Gulf coasts of Florida and are surrounded by sugar, citrus, and winter vegetable growers. In recognition of the pressures being exerted upon the Everglades and that many of the treatments and remedies done to the Everglades have created additional problems, the 104th Congress 1995 ( $\$ .640$, section 207) passed the Everglades and South Florida ecosystem restoration bill. On the state level, the Florida Legislature passed the Everglades Forever Act, 1994. Money has been appropriated and work has begun on restoration efforts.

\section{The history of the river}

An example of how the information is being collected and used for researchers involved in Everglades restoration is a small project at Florida Gulf Coast University (FGCU), funded by the South Florida Water Management District. The Caloosahatchee River is a major river flowing from Lake Okeechobee out to the Gulf of Mexico. The river has been dredged, diked, and managed since the early part of the 1920 s, initially to stop floods and then to serve as a link in the inter-coastal waterway from the Atlantic to the Gulf of Mexico. The South Florida Water Management District is attempting to study the Caloosahatchee watershed to see what has happened to the watershed over the past 70 or 80 years. FGCU is collecting all of the documents available to write a history of the river and make the documents accessible to researchers through the Web. This project is made possible because most of the materials are government documents, are in the public domain, and are freely available to the public through government depository programs.

The outcome of this project is twofold: first, a history of the river and the watershed will document the treatments and remedies and their impact on the Everglades to the south of the river; and second, the combined collection of local, state, and federal documents will provide a single resource base for researchers to understand the studies conducted, the changes over time, and will help researchers define a research agenda for the future. The ideal outcome will be for policy makers, researchers, and environmental groups to realize the importance of a coordinated effort to avoid the costly mistakes of the past.

The wealth of information available to review is staggering and the accumulated data are helping policymakers and scientists come up with strategies for restoration. Without the availability of government documents collected and preserved through the Federal Depository Program, many of the crucial pieces of information may very well have been lost.

\section{Send your stories}

Academic librarians in particular need to find real life examples and develop stories that illustrate the strategic value of government documents for research and education. The ALA Washington office can use these stories in their lobbying efforts with Congress. Please share your stories by sending them to Michael Godow at ACRL: mgodow@ala.org.Carolyn M. Gray is chair ACRL Government Relations Committee, and dean of library'services at Florida Gulf Coast University; cgray@ fscu.edu 
many possible evolutionary paths exist. First, whatever role the government plays, it should not be overly directive. Secondly, Internet engineers now talk about establishing a close coupling between applications and infrastructure design. New Internet technology seems likely to advance along a spiral process in which improvements are made, new applications are tried, new needs identified by the users, and new basic advances made.

Four particular areas were identified in a federally sponsored workshop held in Washington, D.C. last spring.

- Reservable quality of service. As the Internet becomes more complicated and carries an increasing variety of uses, users chafe against a one-size-fits-all design. Internet resources should be allocated according to the needs of the job. E-mail requires one level of service; real-time remote telesurgery requires another. Bandwidth is only one dimension of service; delay, reliability, time of day, are also important parameters.

- Security. The Internet is certainly not a very secure or reliable environment, although it is improving. As the world grows more dependent on this infrastructure, the vulnerabilities and potential costs of failure continue to increase. These threats will exist in the best of systems, but the NGI will certainly need to be more secure and robust.

- Middleware. Many of today's common Internet applications-e-mail, the World Wide Web, and many others-depend on agreed standards that are imbedded in software at user and server nodes. NGI applications, which will be much more complex, will depend not only on shared standards, but on intelligence imbedded within the network itself. They will incorporate sets of basic application tools and services provided by the network.

- Network management. One cannot manage and improve a technology without proper measurement and tools. These days, network designers and Internet service providers operate pretty much in the dark, guessing about the sources of congestion and unreliability more than analyzing. They will need to be able to instrument its performance and model its behavior.
.. . the network has been a

victim of its own success. Having

tasted a limited set of

possibilities, many would-be

users and service providers are

beginning to dream about what

could be offered with even more

bandwidth and sophisticated

transmission services . . .

\section{State of the debate}

Last year, both Senate and House committees with science oversight were critical of the program for various reasons, and appropriations for FY 98 fell short of the administration's request of $\$ 105$ million. Department of Energy funding was reduced substantially. (There were no appropriations, but the agency was allowed to reprogram some existing funds.) Furthermore, although NSF funding was, in theory, increased by $\$ 13$ million over its $\$ 10$ million request, the appropriations committee directed NSF to take the money from a fund created from fees collected for domain-name registration.

The domain-name issue has become a major controversy in itself. The fund has been the subject of a law suit, and a federal judge recently froze the use of that money. NSF has not decided what to do next. Presumably some of the missing money, at least the $\$ 10$ million originally requested, will be found somewhere in NSF's budget, but that would still leave overall NGI funding substantially below the FY 98 request.

There are many reasons offered for these difficulties. Administration officials complained about politics and misunderstanding on the part of Congress. Members of congressional committees and staff complained about a lack of leadership and delay on the part of the administration.

Congressional and administration critics may both be right. The program has been relatively slow to come together. And, even though the Republican Congress seemed sympathetic toward NGI, it wasn't about to make life easy for the administration. 
But there also are several structural reasons for the difficulties, the first of which is the difficulty inherent in coordinating a multiagency program.

With the exception of the NSF, which supports basic science for its intrinsic worth and for the broad social benefits it brings, federal agencies fund research in information technology because it is vital to their particular missions. These agencies want to develop more sophisticated data communications technology to serve their own needs. The logic underlying the multiagency program is that, by coordinating and fine-tuning these various efforts, one can see that they also contribute to broader social needs. But, that is not easy. Each agency manages its R\&D programs to meet its own needs, and tight budgets and demanding constituencies make it difficult for them to broaden or redirect their programs.

Further, selling the program to Congress can be tough work. Each agency must get its own part of the program approved by its authorizing and appropriation subcommittees in Congress. As of now, there is no crosscutting NGI authorization, and appropriation is always agency-by-agency. Each subcommittee can have different views about its agency's role in the program.

Another structural difficulty is the confusion between research and infrastructure building that is inherent in so much information technology R\&D. Building systems to test concepts is a basic technique for computing and communications researchers. Prototypes not only allow researchers to test laboratory ideas in a more realistic environment, they provide a testbed for higher level applications research. ARPAnet served not only as a system for testing packet-switching and Internet protocols, it became a platform for research on how to use communications to support research.

That was not a problem in the days when ARPAnet was first built. Few noticed or cared that ARPA was building network infrastructure in its research programs. But, these days, public interest in the Internet means that the NGI program operates in a fishbowl. No matter how experimental the network is it creates, politicians will ask questions about who benefits and who gets access. Agen- cies go to Congress expecting to sell a research effort and get asked why some university in a rural state isn't part of the program (even though that university may have no significant communications research going on the campus). The real dilemma is that the question is not unreasonable. The politicians know that even connections to a highly experimental advanced network can provide important advantages to a research and educational community.

\section{President's budget request for NGI for FY 99 (in millions)}

$\begin{array}{ll}\text { Defense Advanced } & \\ \text { Research Projects Agency } & \$ 40 \\ \text { National Science Foundation } & \$ 25 \\ \text { Energy } & \$ 25 \\ \text { National Aeronautics and } & \\ \text { Space Administration } & \$ 10 \\ \text { National Institute } & \\ \quad \text { of Standards and Technology } & \$ 5 \\ \text { National Library of Medicine } & \$ 5\end{array}$

The NGI program, though principally defined as a research program, will have to address equity of access issues and deployment policies as an integral part of the program design if it is to gain significant political support.

\section{Current status}

The White House still seems confident in the program, feeling that some of the misunderstandings and confusions of last year have been cleared away. Clinton mentioned NGI in his State of the Union. The budget request calls for a significant increase over last year (see chart). It also reflects two ALA priorities expressed in comments made last spring to the administration: that the $\mathrm{Na}$ tional Library of Medicine should participate and that NSF should play a larger role. (Last year's NSF request of $\$ 10$ million was surprisingly low compared with most other participating agencies.)

A bipartisan group of Senators have cosponsored an NGI authorization bill, S. 1609 , that has been submitted in the Senate. The sponsors represent the senior leadership on the Senate Committee on Commerce, Science, and Transportation and its key subcommittees on Science and 


\section{ACRL's legislative agenda}

The ACRL Board approved this legislative agenda at its 1998 Midwinter Meeting upon recommendation of the Government Relations Committee.

\section{NGI and Internet2}

Actions recommended:

- Educate library administrators about the potential importance of these projects for libraries.

- Educate the high performance computing policymakers and developers at the local, state, and national levels as to the needs of libraries for high bandwidth computer capabilities.

- Publish an article by Rick Weingarten of the ALA Washington Office in CERL Neus about NGI activities.

- Follow policy and legislative developments through the Internet2 Web site: wuw internet2.edu and the Presidential Advisory Committee on High Performance Computing and Communications, Information Technology, and the Next Generation Internet: www hpcc.gov/ac.

\section{Intellectual property}

Actions recommended:

- Encourage ACRL members, through the ACRL Legislative Network and ACRL Leads, to write their congressmen and senators to get cosponsorship of critical copyright legislation. These bills are Senator John Ashcroft's (R-Missouri) Digital Copyright Clarification and Technology'Act (S. 1146) and the Digital Era Copyright Enhancement Act (H.R. 3048), jointly introduced by Representatives Rick Boucher (D-Virginia) and Tom Campbell (R-California). Send the ALAWON Alert again, as the other was so close to the holidays and may not have been acted upon.

on Communications. There are reports that the Science Committee of the House of Representatives is working on its own bill that should be introduced some time in March. Staff from both House say that there is potentially strong support for some form
- Ask the ACRL President to send a letter to the directors of all ACRL institutional members urging them to contact their institution president and lobbyist, when appropriate, to brief them on critical copyright issues. Colleges and universities are to urge their national higher education associations, such as AAU, to support pending legislation.

Print the four library association presidents' "Open letter to the library community" in the next CERL News (Feb. 1998).

Disseminate the Principles for Licensing Electronic Resources and encourage broad experimental use. The Principles may be found online at www.ala.org/ washoff/confu.btml.

\section{Government information}

The inter-association working group has sent a legislative proposal to congressional staff to amend the Depository Library Act (44 USC 19). The draft bill is entitled the "Federal Information Access Act." If legislation is introduced, we want to make sure the working group's goals are included. The goals and explanatory text can be found at bttp://ww' lib.berkeley.edu/ GODORT/iawgfnl.html.

\section{Actions recommended:}

- Encourage a member to write, with a member of the teaching faculty, an opinion piece for the Chronicle of Higher Education to clarify the importance of the Federal Depository program to teaching and learning.

- Through CERL New's and the ACRL Legislative Network, solicit "stories" from the field to send to the Washington Office giving real-life examples of the use of documents in teaching and learning (see page 255 ).

- Encourage members to take action if legislation is proposed.

of legislation, although the schedule to move a bill is growing tight. That means that the bill will have to be low-key and noncontroversial, since any delay whatsoever will result in the bill being set aside for the 106th Congress to consider. 